\title{
The Notion of Complex Equality and the Beauty of Alcibiades
}

Marc Hooghe - Vrije Universiteit Brussel

One of Prof. Walzer's most fascinating contributions to the field of political theory is his introduction of the concept of 'complex equality'. In Spheres of Justice, he defines this concept as follows: "In formal terms, complex equality means that no citizen's standing in one sphere or with regard to one social good can be undercut by his standing in some other sphere, with regard to some other good. Thus, citizen $X$ may be chosen over citizen $\mathrm{Y}$ for political office, and then the two of them will be unequal in the sphere of politics. But they will not be unequal generally so long as X's office gives him no advantage over $\mathrm{Y}$ in any other sphere - superior medical care, access to better schools for his children, entrepreneurial opportunities, and so on" (Walzer 1983, 19). To achieve a situation of complex equality, Prof. Walzer proposes a system of blocked exchanges: it should be avoided that goods obtained in one sphere are exchanged to obtain goods in another sphere. For instance, the money person $\mathrm{X}$ has acquired in the economic sphere should not be used to 'buy' power and influence in the political sphere.

Prof. Walzer states that this system of complex equality will lead to a more egalitarian distribution of social goods. Maybe in each sphere distinct inequalities will persist, but given the plurality of spheres, eventually every person will acquire goods in one sphere or another. This line of reasoning reminds us to some extent of the traditional pluralist argument as it was formulated by Robert Dahl (1961). Dahl asserts that in contemporary American society, no single group actually dominates political decision-making, since the power of even very influential groups is limited to a few policy arenas. Even underprivileged groups have enough access to proper channels to let their voice get heard in political decision-making.
The basic argument is that inequalities are acceptable within one sphere, but we cannot permit these inequalities to be cumulative, overlapping or even reinforcing one another. An accumulation of these inequalities can be the result of two different processes. Firstly, the influential position within one sphere can be used to gain access to a similar position in a different sphere. The notion of complex equality is aimed mainly at eradicating the possibility of this kind of exchange. The second possible relation, however, is that power positions within two (or more) different spheres originate from a single, common cause. This would imply that citizen $\mathrm{X}$ has one single characteristic, which makes her successful, both in literature, as in politics and in economic entrepreneurship. The theory of complex equality does not explicitly address this possible cause of cumulative inequalities. Prof. Walzer more or less denies the possibility that this kind of distribution can actually occur. He gives the fictive example of a person who is a bold and inventive entrepreneur, who scores amazingly high grades in every exam, who is brave during the war, and who is loved by all who know him. Walzer goes on: "Are there such people? Maybe so, but I have my doubts (...) In any case, there aren't enough such people to constitute a ruling class and dominate the rest of us. Nor can they be successful in every distributive sphere, for there are some spheres in which the idea of success doesn't pertain" (Walzer 1983, 20). Given this plurality of talents and spheres, a system of complex equality effectively prevents processes of exclusion and the formation of an underclass (Walzer 1993). This aspect of the theory has already received quite some critical attention (Miller 1995), but I still wonder whether Prof. Walzer does not underestimate the ubiquity of these processes of cumulative inequality. 


\section{( )}

Let me start with what is probably the most ancient example of this kind of sphere-transgressing assets of an individual, which we find in the description of the speech by Alcibiades in the Symposium of Plato (1963, 564-574). Alcibiades stumbles in late during the discussion, completely drunk, but nevertheless he immediately captures everyone's attention. This is to a large extent the result of the extraordinary reputation Alcibiades enjoys and which is summarized quite neatly by Nussbaum (1986, 165): "He was, to begin with, beautiful. He was endowed with a physical grace and splendor that captivated the entire city (...) $\mathrm{He}$ was always highly conscious of his body, vain about its influence. He would speak of his beauty as his 'amazing good fortune' and his 'windfall from the gods'. But this was not the limit of his natural gifts. Energy and intellectual power had made him one of the best commanders and strategists Athens had known, one of the most skillful orators ever to enchant her people". Of course, Walzer is right: the number of people who are blessed, like Alcibiades, with such a host of talents will be rather small. But in daily life, the phenomenon that people use their talents simultaneously in more than one sphere, is quite widespread. Intelligent people not only have better chances of doing well at school, they also have more opportunities to be economically successful, and when they venture into politics, they will normally acquire more influence than people who have less intelligence. If we stick to physical beauty, people possessing this beauty will not only be more successful in the romantic sphere, they will also (as Aristotle already reminds us) find it easier to get new friends, to get jobs, etc. Even a simple feature like the way people look can be a bonus in numerous spheres. If someone is successful in being an actor, the same talents will make him successful in being a governor of California, or even in acting like the president of the United States.

While the theory of complex equality addresses the problem of exchange between spheres (situation A), it pays little attention to the widespread phenomenon of the multiple application of talents (situation B). The success of Alcibiades does not depend on an exchange between various spheres. It isn't as though Alcibiades first uses his physical beauty to seduce important people, and then in a subsequent stage uses this friendship to acquire political power. This kind of exchange would indeed be completely blocked in Walzer's system of complex equality. The situation as described in the Symposium, however, is altogether different. We do not witness an exchange phenomenon, but rather a direct relation between, on the one hand, the physical beauty of Alcibiades, and on the other hand his erotic and social success. It is precisely because he is so attractive that people also like to listen to him.

Of course, physical beauty is but one (and even then a rather innocent) example of a personal characteristic which can be put to use in many different spheres. The most obvious example would of course be the possession of cognitive abilities. People possessing these abilities will put them to use in educational, economic and political spheres, and blocking exchanges between the spheres will not prevent the occurrence of this kind of cumulative inequality.

To a large extent, Prof. Walzer is right in proposing that there is a large pluriformity in formats of intelligence. Those with musical intelligence will not necessarily also enjoy verbal talents or mathematical intelligence. It would be naive to assume that there exists something like an absolute form of intelligence, of which the various kinds of intelligence we can observe are only manifestations. Nevertheless, we do know that there exists a strong interrelation between the various forms and manifestations of intelligence (Sternberg 1985; McShane 1991; Detterman \& Sternberg 1993). If we see that pattern recognition and application, or thinking within analogies are basic features of intelligence, it seems evident that these features can be put to use in education, economics, science, as well as in politics. 
If we want to achieve a complex equality across spheres, how can we prevent person $\mathrm{X}$ from using her intelligence both in the economic sphere and in the political sphere? We can prevent her from using money to buy votes, but we cannot prevent her from having talents which can be used in a number of spheres. A typical example of this kind of selfenforcing inequality is the relation between participation in the educational sphere and participation in the political sphere. Empirical research shows that there is a strong correlation between political participation - thus gaining political influence - and educational attainment. Those with little education often abstain from participation because they have the feeling that they do not really have the resources to play a meaningful role in the political sphere. The same cognitive abilities which we assume to be essential in the educational system are also crucial for playing an effective role in the political system (Hooghe 1999a, 1999b).

One cannot outlaw the use of intelligence by one person in various spheres, and I don't have the impression that this is what Prof. Walzer is aiming at. He states: "Men and women who are ambitious to exercise power must collect votes, but they can't do that by purchasing them; we don't want votes to be traded in the marketplace (...) The only right way to collect votes is to campaign for them, that is to be persuasive, stimulating, encouraging, and so on" (Walzer 1980, 247). This seems a straightforward meritocratic criterion, but maybe it underestimates the traditional pitfall of a meritocratic system: it does not necessarily reduce inequalities. Those with little merits remain out of the system, and this is true both for the economic, as for the educational and political spheres (Elchardus 1996).

There are but few possibilities to reconcile meritocracy with a more or less egalitarian distribution of social goods. A possible solution is a strict rationing of social goods. That is in fact what we do with political power, by distributing one vote to every citizen. By imposing monogamy, society to some extent also rations relational, emotional and sexual resources. But rationing social goods in the economic or educational sphere seems a less obvious strategy. The multiple utilization of talents and abilities in different contexts implies that the blocking of exchanges between various spheres is not sufficient to arrive at an egalitarian distribution of social goods. Such a distribution rather calls for a system of mandatory compensation, in which the state extracts the surplus one acquires in one sphere, to arrive at a more egalitarian distribution in another sphere. The state takes money from the rich, and uses it to provide educational opportunities for those who would not have access to prolonged education in simple market conditions. If we really want an equal distribution of social goods across the spheres, we would even have to introduce a system of compensatory taxes, as Philippe Van Parijs (1995) suggests. In one of the examples he develops, Van Parijs starts from the observation that those possessing a more than average physical beauty will have an easier life than those who have not. Therefore, it seems fair to him to levy taxes on attractiveness. Although the introduction of such a tax does not really seem feasible, the idea indicates clearly that blocking exchanges between the spheres will not be sufficient to ensure a more or less equal distribution of social goods. Therefore, the problem remains how the concept of complex equality can be reconciled with the multiple use of talents and abilities. How can we prevent Alcibiades from using his beauty, not only to seduce lovers (which seems appropriate in that sphere), but also to charm audiences, to influence juries, to get high grades in university examinations, and to get a lot of votes for his political party? 


\section{References}

Robert DAHL (1961), Who Governs? New Haven, Yale University Press.

Douglas DETTERMAN \& Robert STERNBERG (eds.) (1993), Transfer on Trial: Intelligence, Cognition, and Instruction. Norwood, Ablex.

Mark Elchardus (1996), 'Class, Cultural Re-Alignment, and the Rise of the Populist Right' in A. ERSKINE, M. Elchardus, S. Herkommer \& J. RYAn (eds.), Changing Europe: Some Aspects of Identity, Conflict and Social Justice. Avebury, Aldershot. p. 41-63.

Marc HOOGHE (1999a), 'Cumulatieve participatiepatronen en de democratiserende functie van het verenigingsleven', in Sociale Wetenschappen, 42(1999)3, in press.

Marc HoOGHe (1999b), 'Politiek, da's niets voor mij”. Adaptieve preferentievorming als causaal mechanisme bij politieke passiviteit' in Tijdschrift voor Sociologie, 20(1999)1, in press.

John MCShane (1991), Cognitive Development: An Information Processing Approach. Oxford, Blackwell.

David Miller (1995), 'Complex Equality', in David Miller \& Michael WAlzer (eds.), Pluralism, Justice, and Equality. Oxford, Oxford University Press, p. 197-225.

Martha Nussbaum (1986), The Fragility of Goodness: Luck and Ethics in Greek Tragedy and Philosophy. Cambridge, Cambridge University Press.

Philippe VAN PARIJS (1995), Freedom for All: What (if anything) can Justify Capitalism? Oxford, Clarendon Press.

Plato (1963), Collected Dialogues. Ed. Edith Hamilton \& Huntington Cairns. Princeton, Princeton University Press.

Robert Sternberg (1985), Beyond IQ: A Triarchic Theory of Human Intelligence. Cambridge, Cambridge University Press.

Michael Walzer (1980), Radical Principles: Reflections of an Unreconstructed Democrat. New York, Basic Books.

Michael WALZER (1983), Spheres of Justice: A Defence of Pluralism and Equality. New York, Basic Books.

Michael WALZER (1993), "Exclusion, Injustice, and the Democratic State", Dissent, 40, 55-64. 